\title{
Mucosal inflammation in idiopathic bronchiectasis: cellular and molecular
} mechanisms

\author{
S. Fuschillo, A. De Felice and G. Balzano
}

ABSTRACT: Bronchiectasis is a chronic and debilitating lung disease, characterised by irreversible dilatation of the bronchi as consequence of airway injury and remodelling due to recurrent or chronic airway inflammation and infection. The underlying aetiologies include autoimmune diseases, severe infections, genetic abnormalities and acquired disorders.

The pathogenesis of bronchiectasis is poorly understood. Three distinct pathogenetic elements, namely infection, inflammation and enzymatic actions, which interact with each other, have been implicated in the pathophysiology of bronchiectasis.

Some recent observations indicate that airway inflammation in bronchiectasis comes from a deregulated cytokine network independent of bacterial airway colonisation.

In the present review, current knowledge about cellular and molecular inflammatory events in the dynamic process of host-pathogen interaction that are thought to play a relevant role in the pathogenic mechanisms of airway wall destruction leading to bronchiectasis are discussed.

KEYWORDS: Airway infection, airway inflammation, bronchiectasis

B ronchiectasis is a pathological description of a progressive and debilitating disease in which airways become permanently dilated as the result of inflammatory-related destruction of structural components of the bronchial wall [1, 2]. In general, as shown in table 1, bronchiectasis represents the end stage of several pathological processes, ranging from foreign body obstruction to post-infectious damage, genetic defects, altered host defence and autoimmune disease [3]. However, the underlying cause may be impossible to identify in about $50 \%$ of cases [4].

The disease can manifest itself in either of two forms: limited to one area (localised) or more widespread (generalised) and often accompanied by rhinosinusitis and diffuse airflow obstruction [2]. The clinical course is characterised by a persistent or recurrent cough, purulent sputum production, occasional haemoptysis, recurrent exacerbations, fatigue and shortness of breath [1].

Although patients with idiopathic bronchiectasis have early onset disease, nowadays the age of onset has become later due to improved sanitation, introduction of childhood immunisation and the early and frequent use of antibiotics.

The clinical spectrum of the disease is broad. A small subset of patients, for reasons that are unknown, develops early onset and rapidly progressive disease. Another subset of patients, that constitutes the vast majority, appear to deteriorate slowly over decades from an increase in exacerbation frequency, sputum volume and extent of bronchiectasis. Finally, some patients, usually those with single lobe involvement, can be asymptomatic between exacerbations and not deteriorate even after decades [5].

The quality of life of affected subjects is often severely impaired and, due to frequent admissions to hospital, the socioeconomic cost of the disease is high [6].

The pathogenetic mechanism leading to bronchiectasis is complex and, to date, not well understood. The current point of view considers that an exaggerated and uncontrolled neutrophilic airway inflammatory response triggered by bacterial infection of the lower respiratory tract is the first step in the pathogenetic mechanism leading
AFFILIATIONS

Division of Pneumology, "Salvatore Maugeri" Foundation, Scientific Institute of Telese Terme, Telese Terme, Italy.

CORRESPONDENCE

S. Fuschillo

Division Of Pneumology

Scientific Institute of Telese Terme (BN)

"Salvatore Maugeri" Foundation

Telese Terme (BN)

82037

Italy

Fax: 39824909614

E-mail: sfuschillo@fsm.it

Received:

June 112007

Accepted after revision:

September 242007

STATEMENT OF INTEREST

None declared.

European Respiratory Journal

Print ISSN 0903-1936

Online ISSN 1399-3003 
to bronchiectasis [7-9]. Based on this view, airways are progressively damaged as the result of the interplay between microbial infection, airway inflammation and tissue-damaging substances secreted by neutrophils [9-11].

Some observations indicate that airway inflammation in bronchiectasis comes from a deregulated cytokine network [12-14], independent of bacterial airway infection. In the early phases of both cystic fibrosis [12, 15-17] and bronchiectasis [14], active airway inflammation has been reported even in the absence of microbial infection.

\section{AIRWAY INFLAMMATION AND INFECTION}

Knowledge about airway inflammation in chronic airway inflammatory disorders has increased considerably in recent years, thanks to the application of methods such as bronchoalveolar lavage (BAL), bronchial biopsy and, more recently, induced sputum [18, 19]. However, despite considerable progress being made in the understanding of airway inflammation in asthma and chronic obstructive pulmonary disease (COPD), little is known of this in bronchiectasis [20].

Host defence and inflammatory response are based on a complex cytokine network that leads to the activation and expansion of cells involved in the immune response [21]. Severity of inflammatory response depends on the interplay between pro-inflammatory cytokines, which are upregulated, and anti-inflammatory cytokines and various cytokine inhibitors, which are released to limit its extent and duration [22]. So, pro-inflammatory cytokines released in response to injury or infection when not adequately counterbalanced by anti-inflammatory cytokines cause a local or systemic pathology [21].
In idiopathic bronchiectasis, chronic bronchial infection and inflammation interacting with each other are responsible for progressive lung damage [23].

The kinetics of the establishment of infection and their relationship with the subsequent inflammatory response are poorly understood [24]. Generally, airway inflammation has been considered a consequence of airway infection rather than a prelude to it [15].

An abnormal cytokine network and/or uncontrolled activation of effector cells can manifest itself as inflammation independent of infection and/or inflammation disproportionately increased or prolonged in relation to the level of bacterial stimuli [25]. Recent evidence suggests that in bronchiectasis, airway inflammatory response triggered by bacterial stimulation is excessive in relation to the bacterial burden, and continues to reverberate even after the infection is controlled [26]. The altered homeostasis of airway inflammatory response to bacterial infection in the dynamic process of host-pathogen interaction dictates the clinical manifestations of the lung disease.

Commonly, bronchiectasis airways are infected by bacteria such as Haemophilus influenzae, Streptococcus pneumoniae and Pseudomonas aeruginosa [27, 28].

\section{Pseudomonas aeruginosa infection}

$P$. aeruginosa is an opportunistic pathogen rapidly cleared from airways of healthy subjects [29]. In cystic fibrosis and bronchiectasis subjects it is responsible for chronic infection [23].

\section{TABLE 1 Disorders predisposing to bronchiectasis}

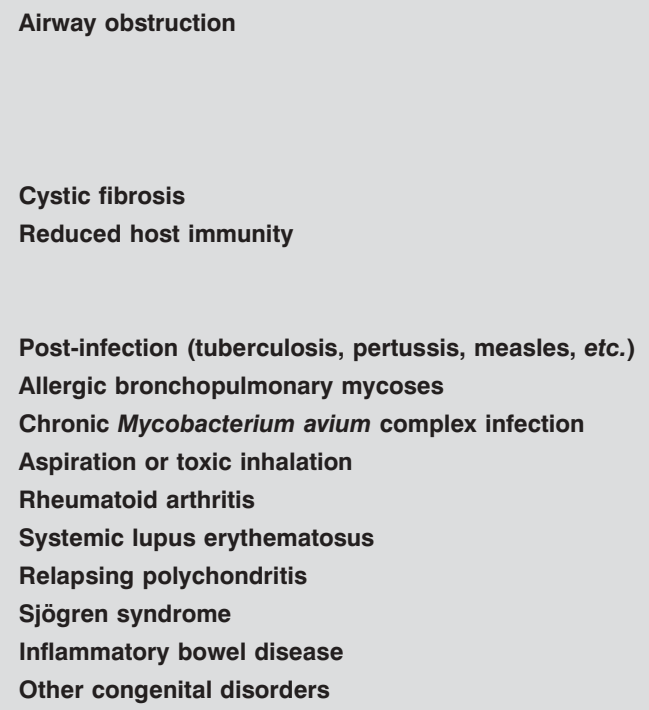

Foreign body

Tumour

Broncholithiasis

External compression of bronchus

Congenital and acquired hypogammaglobulinaemia Malignancy

HIV infection

\author{
$\alpha_{1}$-Antitrypsin deficiency \\ Primary ciliary dyskinesia \\ Tracheobronchomegaly (Mounier-Kuhn syndrome) \\ Bronchial cartilage deficiency (Williams-Campbell syndrome) \\ Young's syndrome (azoospermia and chronic sinopulmonary infections) \\ Bronchopulmonary sequestration \\ Marfan syndrome
}

Yellow nail syndrome (lymphoedema, pleural effusions, hypertrophic nails) 
The virulence of $P$. aeruginosa is multifactorial, including several cell-associated and secreted proteins such as elastase A, phospholipase C, and those translocated through the type III secretion system [30].

LAPA E SILVA et al. [31] have suggested that P. aeruginosa infection, through a cell-mediated immune reaction, has an important role in the pathogenetic mechanism of bronchiectasis.

Alveolar macrophages (AMs) and epithelial cells are a major first line of defence following $P$. aeruginosa lung infection [32, 33]. Stimulated AMs, secreting a number of pro-inflammatory cytokines and chemokines, play a direct role in the recruitment of neutrophils [26, 34].

Activated neutrophils, as indicated by some studies in patients with cystic fibrosis, have been implicated in the induction of a mutation in $P$. aeruginosa leading to alginate production and biofilm formation [35] that protects bacteria from activated neutrophils [36, 37]. The mucoid $P$. aeruginosa biofilms withstand opsonisation and phagocytosis by cells of the immune system [38-40], as well as demonstrating an increased tolerance to toxic oxygen radicals [35, 41] and antibiotics [42]. As a consequence of this mutation, patients develop a vigorous and persistent neutrophilic inflammatory response. Although the change from nonmucoid to mucoid phenotype is more relevant in cystic fibrosis, it is also found in severe bronchiectasis and settles patients into a vicious cycle of airway obstruction, infection and excess inflammation, which results in lung destruction and further damage to the clearance processes [26].

There is accumulating evidence involving natural killer (NK) cells in P. aeruginosa lung infection. Phenotypic differences in NK cells have been shown in mouse strains susceptible and resistant to chronic lung infection with $P$. aeruginosa [43].

NK cells accumulate early in lung parenchyma during inflammation, recruiting other cell types, including neutrophils and T-cells [44, 45].

\section{Mycobacterium avium complex infection}

Mycobacterium avium complex (MAC) is ubiquitous in the environment and, normally, nonpathogenic in healthy subjects $[46,47]$.

MAC infection can cause bronchiectasis and bronchiolectasis [48, 49] in subjects who show no signs of systemic immunological diseases [49-51]. Most of these patients are middle-aged nonsmoking females and have characteristic computed tomographic findings of peripheral nodules and bronchiectasis [52, 53].

Pathologically, MAC lung infection is characterised by extensive granuloma that affect the airways causing airway narrowing and destruction of the airway muscle layer, and can lead to bronchiectasis [49].

In the specific immune response to MAC infection, CD4positive T-cells have a major role $[54,55]$. In addition, NK cells participate in the innate immune response against this pathogen [55-57].

Some observations, both in vitro and in vivo, suggest that specific cytokines and their interplay can confer protection or susceptibility to MAC infection. Tumour necrosis factor (TNF)- $\alpha$ and interferon (IFN)- $\gamma$ are essential for the development of protective immunity against tuberculosis and MAC in mice $[46,54]$. Mice lacking IFN- $\gamma$ or interleukin (IL)-12, a major stimulus for IFN- $\gamma$ production, have increased susceptibility to Mycobacterium tuberculosis $[46,58,59]$ and to $\operatorname{MAC}[46,60]$.

Subjects with genetic deficiencies in IFN- $\gamma$ protein or receptor have increased susceptibility to mycobacterial infection [46, 61]. Several families are reported to be vulnerable to disseminated MAC disease, and their immunocompromise is caused by the decrease in IFN- $\gamma$ production $[62,63]$ or by IFN- $\gamma$ receptor abnormality [64].

\section{Haemophilus influenzae infection}

KING et al. [27] have reported that subjects with bronchiectasis and recurrent infections with nontypeable Haemophilus influenzae (NHTi) present a type 2 T-helper cell (Th2) predominant response with production of IL-4 and IL-10. Conversely, cytokine pattern in control subjects was consistent with a Th1 response. Therefore, it has been suggested that a nonclearing adaptive immune response to chronic infection of the lower respiratory tract in bronchiectasis subjects contributes to the airway inflammatory process [27].

Recently, it has been reported in vivo that NHTi form adherent biofilms on the apical surface of airway epithelium [65]. The epithelium in turn responds through increased secretion of several innate and adaptive immune factors that mediate airway inflammation [65]. H. influenzae stimulates respiratory epithelial production of macrophage inflammatory proteins, IL-8 and TNF- $\alpha$ both in vitro [66] and in vivo [67].

It is also suggested that $H$. influenzae causing airway inflammation can act as a gateway organism, paving the way for colonisation with $P$. aeruginosa [68].

\section{THE ROLE OF CELLS IN BRONCHIECTASIS AIRWAY INFLAMMATION \\ Neutrophils}

Neutrophils play the most relevant role in innate immune responses $[69,70]$. They rapidly migrate into the inflamed tissues and are provided by potent effector mechanisms such as phagocytosis, production of reactive oxygen mediators and antimicrobial substances $[70,71]$.

Neutrophils are the predominant cells present in both sputum and BAL fluid of bronchiectasis subjects [72, 73]. Airway neutrophils are increased in clinically stable bronchiectasis subjects, including those with sterile bronchi, but their numbers further increase when airways are colonised by microorganisms with potential pathogenicity [13].

On bronchial biopsy, high neutrophil densities have been reported in the lamina propria of bronchial mucosa [74, 75].

Neutrophil recruitment to the airways involves a number of pro-inflammatory mediators, including IL- $1 \beta$, IL- 8 , TNF- $\alpha$ and leukotriene $(\mathrm{LT}) \mathrm{B}_{4}[9,10,13,76,77]$.

Transepithelial migration of neutrophils from the intravascular compartment to the sites of inflammation is a regulated multistep process involving a series of coordinated interactions between adhesion molecules expressed on the surface of endothelial cells and their counterparts on leukocytes [78-83]. 
Three families of adhesion molecules mediate this process: the selectins; the integrins CD11/CD18; and the immunoglobulin super-family, including intercellular adhesion molecule (ICAM)-1, vascular adhesion molecule (VCAM)-1 [80, 83-85] and CD47 [86].

These adhesion molecules are upregulated by IL-1, TNF- $\alpha$, lipopolysaccharides [84, 85, 87] and IL-8 [88], all of which are abundant in the airways of subjects with bronchiectasis $[8,9$, $72,74,89]$.

ZHENG et al. [85] have reported that serum levels of E-selectin, ICAM-1 and VCAM-1 were significantly higher in bronchiectasis with regard to control subjects. Interestingly, serum levels of adhesion molecules correlated with functional parameters and sputum volume production suggesting that adhesion molecules take a relevant place in the sequence of the events leading to bronchiectasis [85].

Recently, evidence has been accumulating that Toll-like receptors (TLRs) are modulators of neutrophil-epithelial cell interaction [78]. TLRs recognise specific pathogen-associate molecular patterns and are expressed by most immune cells, including neutrophils and epithelial cells [90]. When TLRs encounter specific pathogen-associate structures, they trigger a signalling cascade that leads to the activation of nuclear factor (NF)- $\mathrm{\kappa B}$ and other transcription factors [91].

Exposure of neutrophils to TLR agonists causes production of IL-8, shedding of L-selectin from the cell surface, upregulation of $\mathrm{CD} 11 \mathrm{~b} / \mathrm{CD} 18$, production of superoxide, and an increase in the rate of phagocytosis [90].

Increased mRNA levels of TLR2 has been reported on sputum supernatant of subjects with bronchiectasis [92].

Adherent neutrophils finally migrate into the airways under the direction of neutrophil chemotractant factors such as IL-8, $\mathrm{LTB}_{4}$ [93-95] and TLR4 agonists [96].

When activated, neutrophils secrete a number of proteases, including neutrophil elastase (NE), catepsin G and proteinase3 [95].

NE has proteolytic effects and induces the release of cytokines, such as IL-6, IL-8 and granulocyte-macrophage colony-stimulating factor [97, 98]. It is also a powerful segretagogue, inducing the expression of the mucin gene MUC5AC via the generation of intracellular reactive oxygen species (ROS) [99].

In steady state bronchiectasis, sputum NE levels correlate with the percentage of neutrophils, pro-inflammatory cytokines (IL8 and TNF- $\alpha$ ) and 24-h sputum volume that is a marker of disease activity [8].

Upon stimulation (TNF- $\alpha$ and IL-1 $\beta$ ) neutrophils also release matrix metalloproteinases (MMPs) [100-102]. Increased levels of MMP-8 and MMP-9 have been reported in BAL fluid of subjects with bronchiectasis [103, 104]. MMP-8 and MMP-9 expression in the bronchiectasis airways correlate significantly with airway neutrophil numbers but not with lung function and extension of disease [105].

Neutrophil toxic products impair the structure and functioning of the airway mucosa by digesting airway elastin, basement membrane collagen and proteoglycan, contributing in this way to the progression of the disease (fig. 1) [8, 99, 105-112].

\section{Macrophages}

The role of macrophages in bronchiectasis is less well defined than that of neutrophils. In bronchial biopsies from bronchiectasis subjects, higher densities of macrophages have been found throughout the entire lamina propria compared with normal controls [74].

A significantly higher number of macrophages has been reported in bronchiectasis subjects with regular sputum production compared with nonproducers, suggesting that airway macrophages could be related to disease activity [74].

Macrophages contribute to neutrophil influx into the airways via the production of TNF- $\alpha$ [75] and endothelin (ET)-1 [113]. They also function as regulatory cells, releasing a number of inflammatory mediators, including TNF- $\alpha$, IL- 8 , other CXC chemokines, monocyte chemotactic peptide $1, \mathrm{LTB}_{4}$, ROS and a number of elastolytic enzymes [95, 114, 115].

VANDIVIER et al. [98] have reported that patients with bronchiectasis had higher levels of apoptotic neutrophils than patients with chronic bronchitis.

Apoptotic cells target themselves for recognition and uptake into phagocyte-expressing surface ligands, in particular phosphatidylserine (PS), which interacts with specific receptors on the macrophages surface [98, 116-118].

PS receptor possesses potential elastase cleavage sites that would result in loss of the putative PS-binding region of the molecule $[98,119]$. It has been reported that NE can cleave the PS receptor on phagocytes, impairing apoptotic cell clearance, contributing in this way to ongoing bronchiectasis airway inflammation [98].

Abnormal accumulation of apoptotic cells results in chronic tissue damage and persistent inflammation [98, 120]. Indeed, apoptosis of dying inflammatory cells is an integral step in the ending of inflammatory response, and failure of this process may have detrimental effects on airways [98, 121].

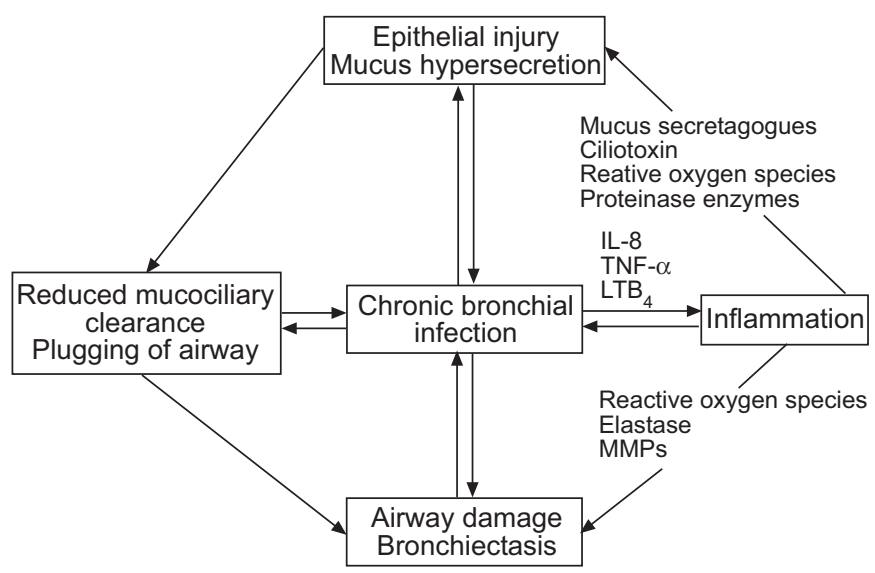

FIGURE 1. Schematic representation of a vicious circle of events which occurs during chronic bronchial infection. IL: interleukin; TNF: tumour necrosis factor; LT: leukotriene; MMP: matrix metalloproteinase. 


\section{Lymphocytes}

In both experimental model [31] and human bronchiectasis [122] T-lymphocytes infiltrate airways. Infiltrating T-cells have been observed, predominantly in the lamina propria, but also dispersed in the epithelium. T-cells are arranged just below the basement membrane of the epithelium, sometimes isolated but usually packed in clusters of cells [122].

Results of available studies on the CD4+/CD8+ ratio have yielded conflicting results. In one study, CD4+ cells were prevalent, with the CD4+/CD8+ ratio being 3:1 in bronchiectasis subjects versus 1.3:1 in control subjects [110]. In another study on BAL fluid, CD4+ and CD8+ cells assessed by flow cytometry were reported in equal numbers [111].

ELLER et al. [72] found that CD8+ cells were predominant in two thirds of patients on bronchial biopsy from 22 subjects with bronchiectasis of diverse aetiology. In the remaining biopsy sections, CD4+ cells were predominant and these were mainly clustered in follicle-like structures [72]. Other studies have reported a predominance of CD8+ T-cells [31, 122]. However, more recent studies have shown that bronchiectasis may be characterised by either increased CD4+ or CD8+ T-cells [72] or, indeed, no predominance of either phenotype [111].

The available data suggest that an ongoing cell-mediated immune response contributes to the inflammatory process observed in bronchiectasis [31, 75, 122].

The importance of cytotoxic T-cells is supported by some observations in subjects with one type of "bare lymphocyte syndrome" who lack transporter associated with antigen presentation (TAP) and cannot put major histocompatibility complex (MHC) class I molecules on their surface. In these patients, CD8+ T-cells are lacking, because they cannot be positively selected in the thymus, which lacks MHC class I expression. Without expression of MHC class I and CD8+ Tcells, these patients suffer from persistent respiratory viral and bacterial infections. A consequence of these repeated respiratory infections is the development of anatomic damage to the airways that, ultimately, results in bronchiectasis [123-125].

NK cells have been implicated in the development of familial bronchiectasis in subjects with TAP gene mutation which, impairing Class I molecule expression, results in NK cell dysfunction [123]. The role of NK cells in bronchiectasis has recently received support from the work of BOYTON et al. [126], who have reported that subjects with human leukocyte antigen (HLA)-c group 1 homozygosity are genetically susceptible to bronchiectasis. HLA-c group 1 homozygosity and the interplay between HLA-c/KIR genes causes excessive or inappropriate activation of NK cells, suggesting a role of these cells in the pathogenetic mechanisms of the disease [126].

\section{Eosinophils}

The role of eosinophils in the pathogenetic mechanism of bronchiectasis is, at the moment, unknown. In bronchiectasis, an increased number of EG2+ eosinophils in the bronchial mucosa has been reported, although their number was smaller than neutrophil, macrophage and T-cell numbers [75]. An increased number of eosinophils has also been observed in the sputum of patients with bronchiectasis [127].
In adult subjects with idiopathic bronchiectasis, serum eosinophilic cationic protein (ECP) levels have been reported to be significantly increased compared with sex- and agematched controls and COPD patients. In contrast, blood eosinophil counts were not increased compared with normal controls or patients with COPD [128].

Airway eosinophil activation is a feature of COPD exacerbations and is linked to disease severity [129].

The clinical and pathological significance of increased airway eosinophil infiltration and serum ECP levels in bronchiectasis subjects are, at the moment, not known, but it is possible that recruitment of eosinophils in the bronchiectasis airway is related to disease severity.

\section{Epithelial cells}

Until recently, the respiratory epithelium has been considered as a physicochemical barrier provided by several constitutive innate mechanisms (e.g. mucociliary clearance, antibacterial molecules, resident macrophages and lymphocytes) that constantly defend airways from harmful inhaled irritants, viruses and bacteria [130, 131].

There is increasing evidence that airway epithelium actively participates in the pathophysiological mechanisms of respiratory disease [132]. Bronchial epithelial cells synthesise and release a number of pro-inflammatory factors, both constitutively and in response to external stimuli [133], providing a local mechanism to induce, amplify or modulate ongoing inflammation [132].

Human bronchial epithelial cells, when exposed to bacterial endotoxin, markedly increase the expression and/or release of pro-inflammatory mediators, including IL- 8 and TNF- $\alpha$, which have a pivotal role in migration and activation of neutrophils to sites of inflammation [77, 133].

Human airway epithelial cells produce ET-1, which promotes neutrophil adhesion to endothelial cells, migration to areas of inflammation and the release of elastase in vitro [113].

Bronchial epithelial cells express ICAM-1 both directly by epithelial cell interaction with bacteria and/or indirectly by epithelial cell communication with other cell types through cytokines [134]. Airway response to bacterial pathogens is modulated by increased expression of ICAM-1 [66, 134]. Interaction of ICAM-1 with CD11/CD18 on leukocytes is determinant for leukocyte adhesion to airway epithelial cells $[90,135]$ and decreased ICAM-1 expression or function may result in impaired leukocyte recruitment and/or antimicrobial activity [134, 136, 137].

Therefore, the current evidence suggests that airway epithelial cells are key orchestrators of inflammatory response through the release of both pro-inflammatory cytokines and the upregulation of ICAM-1 adhesion molecules.

Epithelial cells express TLRs that, when activated, through NF$\kappa \mathrm{B}$ and other signalling molecules, result in transcriptional upregulation of inflammatory mediators [138]. TLRs can also be activated by host-derived molecules and membrane lipids produced as a result of tissue damage [139]. Epithelial cells have many of the cell surface molecules associated with 
antigen presentation, including MHC class I and MHC class II and CD40 [138]. In an experimental rat model of bronchiectasis it has been observed that epithelial cells express MHC class II molecules [31]. It is of interest that emergence of class II MHC antigen in epithelial cells was correlated to the histological severity of bronchiectatic changes [31].

\section{OXIDATIVE STRESS}

Oxidative stress indicates all the functional or structural alterations caused by ROS [140-142]. Normally, toxicity of oxidants and the protective antioxidant defence system are well balanced [143]. During the respiratory burst the excessive quantities of free radicals produced by inflammatory cells overwhelm host antioxidant defences causing severe damage to the airway epithelial cells and other airway structures [144, 145]. However, ROS can exacerbate inflammation, inducing cytokine and chemokine production through stimulation of inflammatory genes controlled by NF-кB [146].

Oxidative stress is believed to play an important role in the pathophysiology of bronchiectasis and other chronic inflammatory respiratory disease such as asthma and COPD [142, $147,148]$.

Activation of neutrophils, eosinophils and macrophages induces a respiratory burst resulting in marked production of superoxide anion, which then undergoes spontaneous or enzyme-catalysed dismutation to form hydrogen peroxide $\left(\mathrm{H}_{2} \mathrm{O}_{2}\right)$ [144].

Increased levels of exhaled $\mathrm{H}_{2} \mathrm{O}_{2}$ have been reported in bronchiectasis subjects [140]. Interestingly, exhaled $\mathrm{H}_{2} \mathrm{O}_{2}$ levels significantly correlated with neutrophil differential counts in induced sputum, extent of disease, lung function impairment and disease severity [73].

Neutrophil is an endogenous source of oxidants [73, 140] and, recently, it has come to light that TNF- $\alpha$ induces neutrophil release of $\mathrm{H}_{2} \mathrm{O}_{2}$ in vitro [149]. This means that the high concentrations of this cytokine observed in bronchiectasis may trigger a prolonged neutrophil release of $\mathrm{H}_{2} \mathrm{O}_{2}$ [140]. Bacterial infections may contribute to oxidative stress by facilitating the recruitment and activation of phagocytic cells in the lung [150]. Indeed, bronchiectasis subjects with $P$. aeruginosa infection present significantly higher levels of $\mathrm{H}_{2} \mathrm{O}_{2}$ compared with bronchiectasis subjects without $P$. aeruginosa infection [73].

Oxidants damage lipids (lipid peroxidation) leading to the production of isoprostanes, of which 8-iso-prostaglandin $\mathrm{F}_{2}$ (8iso- $\mathrm{PGF}_{2}$ ) is the best-characterised isomer. High concentrations of induced sputum 8-iso- $\mathrm{PGF}_{2}$ have been reported in subjects with bronchiectasis and asthma [151, 152].

The levels of oxidative stress indicators, such as $\mathrm{H}_{2} \mathrm{O}_{2}$ or 8isoprostane, in exhaled breath condensate have been shown to reflect the intensity of the underlying inflammation in bronchiectasis [140], asthma [152] and COPD [153].

There are various mechanisms which protect against oxidative stress. One of these is the induction of a stress-response protein, haem oxygenase (HO) $[142,154]$. HO-1, an inducible form of $\mathrm{HO}$, catalyses the degradation of haem to bilirubin, producing free iron and carbon monoxide [155]. A number of cytokines and oxidants, including ILs, TNF- $\alpha$, IFN- $\gamma, \mathrm{H}_{2} \mathrm{O}_{2}$ and nitric oxide are capable of inducing $\mathrm{HO}-1$ [77, 154, 156]. The induction of HO-1 has been shown to be involved in the resolving of acute inflammation under experimental conditions and it has been suggested that it may play a cytoprotective role in haem and oxidant-induced cellular insults [141, 157].

Increased levels of exhaled carbon monoxide have been reported in patients with bronchiectasis as a reflection of increased oxidative stress and consequent HO-1 activation [145].

\section{CONCLUSION}

In the present review, some aspects of mucosal airway inflammatory events in bronchiectasis are briefly covered. The emerging conclusion is that airway bronchiectasis alterations, independent of triggering causes, came from the uncontrolled recruitment and activation of a number of inflammatory cells. The contribution and sequential role of each inflammatory cell implicated in producing the typical pathology of bronchiectasis are still poorly understood.

There are data suggesting that bronchiectasis airway inflammation results from a deregulation of the innate, but also adaptive, immune responses in the context of chronic airway bacterial infection.

It is possible that uncontrolled neutrophil influxes and their activation into the airways is the result of persistent activation of effector mechanisms of innate immunity. In the near future, more research is required to better understand the signalling mechanisms for innate immune responses and the nature of any deficiencies in innate immunity associated with bronchiectasis. The capacity of cytokines to precisely control the movement of inflammatory cells into inflamed airways suggests that cytokines and their receptors might provide targets for therapeutic treatment to modulate airway inflammation, in order to prevent further deterioration in lung function and to better control symptoms.

A number of important questions remain unresolved and deserve further investigation. The presumed triggering events of bronchiectasis are more common than bronchiectasis itself. It is important to understand why some individuals exposed to a triggering event develop permanent damage leading to bronchiectasis while others do not. Similarly, identification of risk factors related to disease progression, particularly in children, is of particular clinical importance since this can allow for early intervention and so minimise long-term morbidity and mortality.

\section{REFERENCES}

1 Cole PJ. Bronchiectasis. In: Brewis RAL, Corin B, Geddes DM, Gibson GJ, eds. Respiratory Medicine. 2nd Edn. London, WB Saunders, 1995; pp. 1286-1316.

2 Barker AF. Bronchiectasis. N Engl J Med 2002; 346: 13831393.

3 Cohen M, Sahn SA. Bronchiectasis in systemic diseases. Chest 1999; 116: 1063-1074.

4 Pasteur MC, Helliwell SM, Houghton SJ, et al. An investigation into causative factors in patients with bronchiectasis. Am J Respir Crit Care Med 2000; 162: 1277-1284. 
5 Tsang KW, Tipoe GL. Bronchiectasis: not an orphan disease in the East. Int J Tuberc Lung Dis 2004; 8: 691-702.

6 Martínez-García MA, Perpiñá-Tordera M, RománSánchez P, Soler-Cataluña JJ. Quality-of-life determinants in patients with clinically stable bronchiectasis. Chest 2005; 128: 739-745.

7 Angrill J, Celis R, Arancibia F, et al. Bacterial colonization in patients with bronchiectasis: prevalence and comparison of diagnostic techniques. Am J Respir Crit Care Med 1999; 159: A559.

8 Pang JA, Cheng A, Chan HS, Poon D, French G. The bacteriology of bronchiectasis in Hong Kong investigated by protected catheter brush and bronchoalveolar lavage. Am Rev Respir Dis 1988; 139: 14-17.

9 Tsang KW, Chan KN, Ho P, et al. Sputum elastase in steady-state bronchiectasis. Chest 2000; 117: 420-426.

10 Tsang KW, Ho PL, Lam WK, et al. Inhaled fluticasone reduces sputum inflammatory indices in severe bronchiectasis. Am J Respir Crit Care Med 1998; 158: 723-727.

11 Cole PJ. Inflammation: a two edged-sword - the model of bronchiectasis. Eur J Respir Dis 1986; 69: Suppl. 147, 6-15.

12 Bonfield TL, Panuska JR, Konstan M. Inflammatory cytokines in cystic fibrosis lungs. Am J Respir Crit Care Med 1995; 152: 2111-2118.

13 Salva PS, Doyle NA, Graham L, Eigen H, Doerschuk CM. TNF- $\alpha$, IL-8, soluble ICAM-1, and neutrophils in sputum of cystic fibrosis patients. Pediatr Pulmonol 1996; 21: 11-19.

14 Angrill J, Agusti C, De Celis R, et al. Bronchial inflammation and colonization in patients with clinically stable bronchiectasis. Am J Respir Crit Care Med 2001; 164: 1628-1632.

15 Khan TZ, Wagener JS, Bost T, Martinez J, Accurso FJ, Riches DW. Early pulmonary inflammation in infants with cystic fibrosis. Am J Respir Crit Care Med 1995; 151: 1075-1082.

16 Balough K, McCubbin M, Weinberger M, Smits W, Ahrens R, Fick R. The relationship between infection and inflammation in the early stages of lung disease from cystic fibrosis. Pediatr Pulmonol 1995; 20: 63-70.

17 Konstan MW, Hilliard KA, Norvell TM, Berger M. Bronchoalveolar lavage findings in cystic fibrosis patients with stable, clinically mild lung disease suggest ongoing infection and inflammation. Am J Respir Crit Care Med 1994; 150: 448-454.

18 Linden M, Rasmussen JB, Piitulainen E, et al. Airway inflammation in smokers with nonobstructive and obstructive chronic bronchitis. Am Rev Respir Dis 1993; 148: 1226-1232.

19 Kirby JG, Hargreave FE, Gleich GJ, O'Byrne PM. Bronchoalveolar cell profiles of asthmatic and nonasthmatic subjects. Am Rev Respir Dis 1987; 136: 379-383.

20 Wilson CB, Jones PW, O'Leary CJ, et al. Systemic marker of inflammation in stable bronchiectasis. Eur Respir $J$ 1998; 12: 820-824.

21 Feldmann M, Maini RN. Anti-TNF $\alpha$ therapy of rheumatoid arthritis: what have we learned? Annu Rev Immunol 2001; 19: 163-196.

22 Wouters EFM. Local and systemic inflammation in chronic obstructive pulmonary disease. Proc Am Thorac Soc 2005; 2: 26-33.
23 Wilson R, Dowlin RB, Jackson AD. The biology of bacterial colonization and invasion of the respiratory mucosa. Eur Respir J 1996; 9: 1523-1530.

24 Chmiel JF, Konstan MW, Saadane A, Krenicky JE, Lester Kirchner H, Berger JM. Prolonged inflammatory response to acute Pseudomonas challenge in interleukin10 knockout mice. Am J Respir Crit Care Med 2002; 165: 1176-1181.

25 Aldallal N, McNaughton EE, Manzel LJ, et al. Inflammatory response in airway epithelial cells isolated from patients with cystic fribrosis. Am J Respir Crit Care Med 2002; 166: 1248-1256.

26 Chmiel JF, Davis PB. State of the art: why do the lungs of patients with cystic fibrosis become infected and why can't they clear the infection? Respir Res 2003; 4: 8.

27 King PT, Hutchinson PE, Johnson PD, Holmes PW, Freezer NJ, Holdsworth SR. Adaptive immunity to non typeable Haemophilus influenzae. Am J Respir Crit Care Med 2003; 167: 587-592.

28 Sadikot RT, Blackwell TS, Christman JW, Prince AS. Pathogen-host interactions in Pseudomonas aeruginosa pneumonia. Am J Respir Crit Care Med 2005; 171: 1209_ 1223.

29 Garau J, Gomez L. Pseudomonas aeruginosa pneumonia. Curr Opinion Infect Dis 2003; 16: 135-143.

30 Travassos LH, Carneiro LAM, Girardin SE, et al. Nod1 participates in the innate immune response to Pseudomonas aeruginosa. J Biol Chem 2005; 280: 3671436718 .

31 Lapa e Silva JR, Guerreiro D, Noble B, Poulter LW, Cole PJ. Immunopathology of experimental bronchiectasis. Am J Respir Cell Mol Biol 1989; 1: 297-304.

32 Adler KB, Fischer BM, Wright DT, Cohn LA, Becker S. Interactions between respiratory epithelial cells and cytokines: relationships to lung inflammation. Ann NY Acad Sci 1994; 725: 128-145.

33 Cheung DOY, Halsey K, Speert DP. Role of pulmonary alveolar macrophages in defense of the lung against Pseudomonas aeruginosa. Infect Immun 2000; 68: 4585-4592.

34 Lu W, Hisatsune A, Koga T, et al. Cutting edge: enhanced pulmonary clearance of Pseudomonas aeruginosa by Muc1 knockout mice. J Immunol 2006; 176: 3890-3894.

35 Mathee K, Ciofu O, Sternberg C, et al. Mucoid conversion of Pseudomonas aeruginosa by hydrogen peroxide: a mechanism for virulence activation in the cystic fibrosis lung. Microbiology 1999; 145: 1349-1357.

36 Jensen ET, Kharazmi A, Lam K, Costerton JW, Høiby N. Human polymorphonuclear leukocyte response to Pseudomonas aeruginosa grown in biofilm. Infect Immun 1990; 58: 2383-2385.

37 Anwar H, Strap JL, Costerton JW. Susceptibility of biofilm cells of Pseudomonas aeruginosa to bactericidal actions of whole blood and serum. FEMS Microbiol Lett 1992; 92: 235-242.

38 Meluleni GJ, Grout M, Evans DJ, Pier GB. Mucoid Pseudomonas aeruginosa growing in a biofilm in vitro are killed by opsonic antibodies to the mucoid exopolysaccharide capsule but not by antibodies produced during chronic lung infection in cystic fibrosis patients. J Immunol 1995; 155: 2029-2038. 
39 Pedersen SS. Lung infection with alginate-producing, mucoid Pseudomonas aeruginosa in cystic fibrosis. APMIS Suppl 1992; 28: 1-79.

40 Simpson JA, Smith SE, Dean RT. Scavenging by alginate of free radicals released by macrophages. Free Radical Biol Med 1989; 6: 347-353.

41 Learn DB, Brestel EP, Seetharama S. Hypochlorite scavenging by Pseudomonas aeruginosa alginate. Infect Immun 1987; 55: 1813-818.

42 Høiby N. Antibiotic therapy for chronic infection of Pseudomonas aeruginosa in the lung. Annu Rev Med 1993; 44: 1-10.

43 Calum H, Moser C, Jensen PØ, Shirai R, Høiby N. Cytokine and surface receptor diversity of NK cells in resistant $\mathrm{C} 3 \mathrm{H} / \mathrm{HeN}$ and susceptible BALB/c mice with chronic Pseudomonas aeruginosa lung infection. APMIS 2003; 111: 891-897.

44 Somersalo K, Carpén O, Saksela E. Stimulated natural killer cells secrete factors with chemotactic activity, including NAP-1/IL-8, which support VLA-4 and VLA5 mediated migration of lymphocytes. Eur J Immunol 1994; 24: 2957-2965.

45 Rollins BJ. Chemokines. Blood 1997; 90: 909-928.

46 Vankayalapati R, Wizel B, Samten B, et al. Cytokine profiles in immunocompetent persons infected with Mycobacterium avium complex. J Infect Dis 2001; 183: 478-484.

47 Greenwell-Wild T, Vázquez N, Sim D, et al. Mycobacterium avium infection and modulation of human macrophage gene expression. J Immunology 2002; 169: 6286-6297.

48 Fujita J, Ohtsuki Y, Suemitsu I, et al. Pathological and radiological changes in resected lung specimens in Mycobacterium avium intracellulare complex disease. Eur Respir J 1999; 13: 535-540.

49 Wittram C, Weisbrod GL. Mycobacterium avium complex lung disease in immunocompetent patients: radiography-CT correlation. British J Radiol 2002; 75: 340-344.

50 Prince DS, Peterson DD, Steiner RM, et al. Infection with Mycobacterium avium complex in patients without predisposing conditions. N Engl J Med 1989; 321: 863-868.

51 Kubo K, Yamazaki Y, Hachiya T. Mycobacterium aviumintracellulare pulmonary infection in patients without known predisposing lung disease. Lung 1998; 176: 381-391.

52 Hartman TE, Swensen SJ, Williams DE. Mycobacterium avium-intracellulare complex: evaluation with CT. Radiology 1993; 187: 23-26.

53 Tanaka E, Amitani R, Niimi A, Suzuki K, Murayama T, Kuze F. Yield of computed tomography and bronchoscopy for the diagnosis of Mycobacterium avium complex pulmonary disease. Am J Respir Crit Care Med 1997; 155: 2041-2046.

54 Appelberg R, Castro AG, Pedrosa J, Silva RA, Orme IM, Minóprio P. Role of $\gamma$-interferon and tumor necrosis factor $\alpha$ during T-cell-independent and -dependent phases of Mycobacterium avium infection. Infect Immun 1994; 62: 3962-3971.

55 Petrofsky M, Bermudez LE. CD4 ${ }^{+} \mathrm{T}$ cells but not $\mathrm{CD} 8^{+}$or $\gamma \delta^{+}$lymphocytes are required for host protection against Mycobacterium avium infection and dissemination through the intestinal route. Infect Immun 2005; 73 2621-2627.

56 Bermudez LE, Kolonoski P, Young LS. Natural killer cell activity and macrophage-dependent inhibition of growth or killing of Mycobacterium avium complex in a mouse model. J Leukoc Biol 1990; 47: 135-141.

57 Bermudez LE, Young LS. Natural killer cell-dependent mycobacteriostatic and mycobactericidal activity in human macrophages. J Immunol 1991; 146: 265-270.

58 Flynn JL, Chan J, Triebold KJ, Dalton DK, Stewart TA, Bloom BR. An essential role for interferon- $\gamma$ in resistance to Mycobacterium tuberculosis infection. J Exp Med 1993; 178: 2249-2254.

59 Cooper AM, Dalton DK, Stewart TA, Griffin JP, Russell DG, Orme IM. Disseminated tuberculosis in interferon- $\gamma$ gene-disrupted mice. J Exp Med 1993; 178: 2243-2247.

60 Doherty TM, Sher A. IL-12 promotes drug-induced clearance of Mycobacterium avium infection in mice. J Immunol 1998; 160: 5428-5435.

61 Murphey ED, Herndon DN, Sherwood ER. $\gamma$-Interferon does not enhance clearance of Pseudomonas aeruginosa but does amplify a proinflammatory response in a murine model of postseptic immunosuppression. Infect Immun 2004; 72: 6892-6901.

62 Tsukaguchi K, Yoneda T, Okamura H, et al. Defective T cell function for inhibition of growth of Mycobacterium avium-intracellulare complex (MAC) in patients with MAC disease: restoration by cytokines. J Infect Dis 2000; 182: 1664-1671.

63 Frucht DM, Holland SM. Defective monocyte costimulation for IFN- $\gamma$ production in familial disseminated Mycobacterium avium complex infection: abnormal IL-12 regulation. J Immunol 1996; 157: 411-416.

64 Dorman SE, Holland SM. Mutation in the signaltransducing chain of the interferon- $\gamma$ receptor and susceptibility to mycobacterial infection. J Clin Invest 1998; 101: 2364-2369.

65 Starner TD, Zhang N, Kim G, Apicella MA, McCray PB Jr. Haemophilus influenzae forms biofilms on airway epithelia. Am J Respir Crit Care Med 2006; 174: 213-220.

66 Frick AG, Joseph TD, Pang L, Rabe AM, St Geme JW 3rd, Look DC. Haemophilus influenzae stimulates ICAM-1 expression on respiratory epithelial cells. I Immunol 2000; 164: 4185-4196.

67 Wang X, Moser C, Louboutin JP, et al. Toll like receptor 4 mediates innate immune response to Haemophilus influenzae infection in mouse lung. J Immunol 2002; 168: 810-815.

68 Smith A. Pathogenesis of bacteria bronchitis in cystic fibrosis. Pediatr Infect Dis J 1997; 16: 91-95.

69 Witko-Sarsat V, Rieu P, Descamps-Latscha P, Lesaure P, Halbwachs-Mecarelli L. Neutrophils: molecules, functions and pathophysiological aspects. Lab Invest 2000; 80: 617-653.

70 Liu Y, Shaw SK, Ma S, Yang L, Luscinskas FW, Parkos CA. Regulation of leukocyte transmigration: cell surface interactions and signaling events. J Immunol 2004; 172: 7-13.

71 Ben-Beruch A, Michiel DF, Oppenhein JJ. Signals and receptors involved in recruitment of inflammatory cells. J Biol Chem 1995; 270: 11703-11706. 
72 Eller J, Lapa e Silva JR, Poulter LW, Lode H, Cole PJ. Cells and cytokines in chronic bronchial infection. Ann NY Acad Sci 1994; 725: 331-345.

73 Loukides S, Bouros D, Papatheodorou G, Lachanis S, Panagou $\mathrm{P}$, Siafakas NM. Exhaled $\mathrm{H}_{2} \mathrm{O}_{2}$ in steady-state bronchiectasis: relationship with cellular composition in induced sputum, spirometry, and extent and severity of disease. Chest 2002; 121: 81-87.

74 Zheng L, Shum H, Tipoe GL, et al. Macrophages, neutrophils and tumor necrosis factor- $\alpha$ expression in bronchiectatic airways in vivo. Respir Med 2001; 95: 792-798.

75 Gaga M, Bentley AM, Humbert M, et al. Increases in CD4+ T lymphocytes, macrophages, neutrophils and interleukin 8 positive cells in the airways of patients with bronchiectasis. Thorax 1998; 53: 685-691.

76 Schleimer RP, Benenati SV, Friedman B, Bochner BS. Do cytokines play a role in leukocyte recruitment and activation in the lung? Am Rev Respir Dis 1991; 143: 1169-1174.

77 Khair OA, Davies RJ, Devalia JL. Bacterial-induced release of inflammatory mediators by bronchial epithelial cells. Eur Respir J 1996; 9: 1913-1922.

78 Reaves TA, Chin AC, Parkos CA. Neutrophil transepithelial migration: role of toll-like receptors in mucosal inflammation. Mem Inst Oswaldo Cruz 2005; 100: Suppl. 1, 191-198.

79 Hogg JC. Leukocyte traffic in the lung. Ann Rev Physiol 1995; 57: 97-114.

80 Adams DH, Sham S. Leukocyte endothelial inter-reactions in regulation of leukocytes and migration. Lancet 1994; 343: 831-835.

81 Carlos TM, Harlan JM. Leukocyte-endothelial adhesion molecules. Blood 1994; 84: 2068-2101.

82 Humlicek AL, Pang LY, Look DC. Modulation of airway inflammation and bacterial clearance by epithelial cell ICAM-1. Am J Physiol Lung Cell Mol Physiol 2004; 287: L598-L607.

83 Bevilacqua MP, Nelson RM. Selectins. J Clin Invest 1993; 91: 379-387.

84 Carlos T, Kovach N, Schwarz B, et al. Human monocytes bind to two cytokine-induced adhesive ligands on cultured human endothelial cells: endothelial-leukocytes adhesion molecule- 1 and vascular cell adhesion molecule-1. Blood 1991; 77: 2266-2271.

85 Zheng L, Tipoe G, Lam WK, et al. Up-regulation of circulating adhesion molecules in bronchiectasis. Eur Respir J 2000; 16: 691-696.

86 Parkos CA, Colgan SP, Liang TW, et al. CD47 mediates post-adhesive events required for neutrophil migration across polarized intestinal epithelia. J Cell Biol 1996; 132: 437-450.

87 Dustin ML, Rothlein R, Bhan AF, Dinarello CA, Springer TA. Induction by IL-1 and interferon- $\gamma$ : tissue distribution, biochemistry and function of a nature adherence molecule (ICAM-1). J Immunol 1986; 137: 245-254.

88 Detmers PA, Lo SK, Olsen-Egbert E, Walz A, Baggioloini M, Cohn ZA. Neutrophil-activating protein-1/ interleukin-8 stimulates the binding activity of leukocyte adhesion receptor CD11b/CD18 on human neutrophils. J Exp Med 1990; 171: 1155-1162.
89 Jatakanon A, Lalloo UG, Lim S, Chung KF, Barnes PJ. Increased neutrophils and cytokines, TNF- $\alpha$ and IL-8 in induced sputum of non-asthmatic patients with chronic dry cough. Thorax 1999; 54: 234-237.

90 Hayashi F, Means TK, Leuster AD. Toll-like receptors stimulate human neutrophil function. Blood 2003; 102: 2660-2669.

91 Akira S. Toll-like receptors and innate immunity. Adv Immunol 2001; 78: 1-56.

92 Simpson JL, Grissell TV, Gibson PG. Innate immune activation in bronchiectasis. Eur Respir J 2004; 24: Suppl. 48, 210 S.

93 Mikami M, Llewellyn-Jones CG, Bayley D, Hill SL, Stockley RA. The chemotactic activity of sputum from patients with bronchiectasis. Am J Respir Crit Care Med 1998; 157: 723-728.

94 Barnes PJ, Shapiro SD, Pauwels RA. Chronic obstructive pulmonary disease. Molecular and cellular mechanisms. Eur Respir J 2003; 22: 672-688.

95 Beeh KM, Kornmann O, Buhl R, Gulpitt SV, Giembycz MA, Barnes PJ. Neutrophil chemotactic activity of sputum from patients with COPD: role of interleukin 8 and leukotriene B4. Chest 2003; 123: 12401247.

96 Fan J, Malik AB. Toll-like receptor-4 (TLR4) signaling augments chemokine-induced neutrophil migration by modulating cell surface expression of chemokine receptors. Nat Med 2003; 9: 315-321.

97 Bédard M, McClure CD, Schiller NL, Francoeur C, Cantin A, Denis M. Release of interleukin-8, interleukin6 , and colony-stimulating factors by upper airway epithelial cells: implications for cystic fibrosis. Am J Respir Cell Mol Biol 1993; 9: 455-462.

98 Vandivier RW, Fadok VA, Hoffman PR, et al. Elastase mediated phosphatidylserine receptor cleavage impairs apoptotic cell clearance in cystic fibrosis and bronchiectasis. J Clin Invest 2002; 109: 661-670.

99 Voynow JA, Young LR, Wang Y, Horger T, Rose MC, Fischer BM. Neutrophil elastase increases MUC5AC mRNA and protein expression in respiratory epithelial cells. Am J Physiol 1999; 276: L835-L843.

100 O'Connor CM, FitzGerald MX. Matrix metalloproteinases and lung disease. Thorax 1994; 49: 602-609.

101 Birkedal-Hansen H. Proteolytic remodeling of extracellular matrix. Curr Opin Cell Biol 1995; 7: 728-735.

102 Corbel M, Lagente V, Boichot E. Pulmonary inflammation and tissue remodeling: role of metalloproteinases. Eur Respir Rev 2000; 10: 260-263.

103 Sepper R, Kontinnen YT, Ding Y, Takagi M, Sorsa T. Human neutrophil collagenase (MMP-8) identified in bronchiectasis BAL fluid, correlates with severity of disease. Chest 1995; 107: 1641-1647.

104 Sepper R, Kontinnen YT, Sorsa T, Koshi H. Gelationolytic and type IV collagenolytic activity in bronchiectasis. Chest 1994; 106: 1129-1133.

105 Zheng L, Lam WK, Tipoe GL, et al. Overexpression of matrix metalloproteinases- 8 and -9 in bronchiectasis airways in vivo. Eur Respir J 2002; 20: 170-176.

106 Stockley RA. Neutrophils and protease/antiprotease imbalance. Am J Respir Crit Care Med 1999; 160: S49-S52. 
107 Doring G. The role of neutrophil elastase in chronic inflammation. Am J Respir Crit Care Med 1994; 150: S114-S117.

108 Shun KY, Chan SCH, Ip MSM. Neutrophil-mediated degradation of lung proteoglycans. Stimulation by tumor necrosis factor- $\alpha$ in sputum of patients with bronchiectasis. Am J Respir Crit Care Med 2000; 162: 1925-1931.

109 Lloberes P, Monserrat E, Monserrat JM, Picado C. Sputum sol phase proteins and elastase activity in patients with clinically stable bronchiectasis. Thorax 1992; 47: 88-92.

110 Stockley RA. The role of proteinases in the pathogenesis of chronic bronchitis. Am J Respir Crit Care Med 1994;1, 50: S109-S113.

111 Sepper R, Kouttinen YT, Ingman T, Sorsa T. Presence, activities, and molecular forms of cathepsin $\mathrm{G}$, elastase, alpha 1-antitrypsin, and alpha 1-antichymotrypsin in bronchiectasis. J Clin Immunol 1195; 15: 27-34.

112 Amitani R, Wilson R, Rutman A, et al. Effects of human neutrophil elastase on bacterial proteinases on human respiratory epithelium. Am J Respir Cell Mol Biol 1991; 4: 26-32.

113 Zheng L, Tipoe G, Lam W-K, et al. Endothelin-1 in stable bronchiectasis. Eur Respir J 2000; 16: 146-149.

114 Punturieri A, Filippov S, Allen E, et al. Regulation of elastinolytic cysteine proteinase activity in normal and cathepsin K-deficient human macrophages. J Exp Med 2000; 192: 789-799.

115 Russell RE, Thorley A, Culpitt SV, et al. Alveolar macrophage-mediated elastolysis: role of matrix metalloproteinases, cysteine, and serine proteases. Am J Physiol Lung Cell Mol Physiol 2002; 283: L867-L873.

116 Fadok VA, de Cathelineau A, Daleke DL, Henson PM, Bratton DL. Loss of phospholipid asymmetry and surface exposure of phosphatidylserine is required for phagocytosis of apoptotic cells by macrophages and fibroblasts. J Biol Chem 2001; 276: 1071-1077.

117 Fadok VA, Voelker DR, Campbell PA, Cohen JJ, Bratton DL, Henson PM. Exposure to phosphatidylserine on the surface of apoptotic lymphocytes triggers specific recognition and removal by macrophages. I Immunol 1992; 148: 2207-2216.

118 Brouckaert G, Kalai M, Krysko DV, et al. Phagocytosis of necrotic cells by macrophages is phosphatidylserine dependent and does not induce inflammatory cytokine production. Mol Biol Cell 2004; 15: 1089-1100.

119 Fadok VA, Bratton DL, Rose DM, Pearson A, Ezekewitz RA, Henson PM. A receptor for phosphatidylserine specific clearance of apoptotic cells. Nature 2000; 405: 85-90.

120 Aprikan AAG, Liles WC, Dale DC. Emerging role of apoptosis in the pathogenesis of severe neutropenia. Curr Opin Hematol 2000; 7: 131-132.

121 Haslett C. Granulocyte apoptosis and its role in the resolution and control of lung inflammation. Am J Respir Crit Care Med 1999; 160: S5-S11.

122 Silva JR, Jones J, Cole PJ, Poulter LW. The immunological component of the cellular inflammatory infiltrate in bronchiectasis. Thorax 1989; 44: 668-673.

123 Sadikot RT, Blackwell TS, Christman JW, Prince AS. Pathogen-host interactions in Pseudomonas aeruginosa pneumonia. Am J Respir Crit Care Med 2005; 171: 1209-1223.
124 Gadola SD, Moins-Teisserenc HT, Trowsdale J, Gross WL, Cerundolo V. TAP deficiency syndrome. Clin Exp Immunol 2000; 121: 173-178.

125 Rosen FS, Cooper MD, Wedgwood RJP. The primary immunodeficiencies. N Engl J Med 1995; 333: 431-440.

126 Boyton RJ, Smith J, Ward R, et al. HLA-C and killer cell immunoglobulin-like receptor genes in idiopathic bronchiectasis. Am J Respir Crit Care Med 2006; 173: 327-333.

127 Ip M, Lauder IJ, Wong WY, Lam WK, So SY. Multivariate analysis of factors affecting pulmonary function in bronchiectasis. Respiration 1993; 60: 45-50.

128 Kroegel C, Schuler M, Forster M, Braun R, Grahmann PR. Evidence for eosinophil activation in bronchiectasis, unrelated to cystic fibrosis and bronchopulmonary aspergillosis: discrepancy between blood eosinophil counts and serum eosinophil cationic protein levels. Thorax 1998; 53: 498-500.

129 Saetta M, Di Stefano A, Maestrelli P, et al. Airway eosinophilia in chronic bronchitis during exacerbations. Am J Respir Crit Care Med 1994; 150: 1646-1652.

130 Ferkol TW, Look DC. Chinks in the armor of the airway: Pseudomonas infection in the cystic fibrosis lung. Am J Respir Cell Mol Biol 2001; 25: 11-13.

131 Travis SM, Singh PK, Welsh MJ. Antimicrobial peptides and proteins in the innate defense of the airway surface. Curr Opin Immunol 2001; 13: 89-95.

132 Devalia JL, Davies RJ. Airway epithelial cells and mediators of inflammation. Respir Med 1993; 87: 405-408.

133 Devalia JL, Campbell AM, Sapsford RJ. Effect of nitrogen dioxide on the synthesis of inflammatory cytokines expressed by human bronchial epithelial cells in vitro. Am J Respir Cell Mol Biol 1993; 9: 271-278.

134 Humlicek AL, Pang L, Look DC. Modulation of airway inflammation and bacterial clearance by epithelial cell ICAM-1. Am J Physiol Lung Cell Mol Physiol 2004; 287: L598-L607.

135 Look DC, Rapp SR, Keller BT, Holtzman MJ. Selective induction of intercellular adhesion molecule- 1 by interferon- $\gamma$ in human airway epithelial cells. Am J Physiol 1992; 263: L79-L87.

136 Qin L, Quinlan WM, Doyle NA, et al. The role of CD11/ CD18 and ICAM-1 in acute Pseudomonas aeruginosainduced pneumonia in mice. J Immunol 1996; 157: 50165021.

137 Schnitzler N, Haase G, Podbielski A, Lütticken R, Schweizer KG. A co-stimulatory signal through ICAM$\beta 2$ integrin-binding potentiates neutrophil phagocytosis. Nat Med 1999; 5: 231-235.

138 Schleimer RR. Glucocorticoids suppress inflammatory but spare innate immune responses in airway epithelium. Proc Amer Thorac Soc 2004; 1: 222-230.

139 Kirschning CJ, Schumann RR. TLR2: cellular sensor for microbial and endogenous molecular patterns. Curr Opin Microbiol Immunol 2002; 270: 121-144.

140 Loukides S, Horvath I, Wodehouse T, Cole PJ, Barnes PJ. Elevated levels of expired breath hydrogen peroxide in bronchiectasis. Am J Respir Crit Care Med 1998; 158: 991-994.

141 Horvath I, Loukides S, Wodehouse T, Kharitonov SA, Cole PJ, Barnes PJ. Increased levels of exhaled carbon monoxide in bronchiectasis: a new marker of oxidative stress. Thorax 1998; 53: 867-870. 
142 Repin JE, Bast A, Lankhorst I. Oxidative stress in chronic obstructive pulmonary disease. Oxidative Stress Study Group. Am J Respir Crit Care Med 1997; 156: 341-357.

143 Barnes PJ. Chronic obstructive pulmonary disease. N Engl J Med 2000; 343: 269-280.

144 Tonnel AB, Wallaert B. Oxidants and bronchial inflammation. Eur Respir J 1990; 3: 987-988.

145 MacNee W, Rahman I. Is oxidative stress central to the pathogenesis of chronic obstructive pulmonary disease? Trends Mol Med 2001; 7: 55-62.

146 Biagioli MC, Kaul P, Singh I, Turner RB. The role of oxidative stress in rhinovirus induced elaboration of IL-8 by respiratory epithelial cells. Free Radic Biol Med 1999; 26: 454-462.

147 Rahman I, Morrison D, Donaldson K. Systemic oxidative stress in asthma, COPD and smokers. Am J Respir Crit Care Med 1996; 154: 1055-1060.

148 Barnes PJ. Reactive oxygen species and airway inflammation. Free Radic Biol Med 1990; 9: 235-243.

149 Von Asmuth EJ, Buurman WA. Endothelial cell associated platelet-activating factor a costimulatory intermediate in TNF- $\alpha$ induced $\mathrm{H}_{2} \mathrm{O}_{2}$ release by neutrophil leukocytes. J Immunol 1995; 154: 1385-1389.

150 Hensen PM, Johnston RB. Tissue injury in inflammation. J Clin Invest 1987; 79: 669-674.
151 Wood LG, Garg ML, Simpson JL, et al. Induced sputum 8isoprostane concentrations in inflammatory airway diseases. Am J Respir Crit Care Med 2005; 171: 426-430.

152 Montuschi P, Corradi M, Ciabattoni G, Nightingale J, Kharitonov SA, Barnes PJ. Increased 8-isoprostane, a marker of oxidative stress in exhaled condensate of asthma patients. Am J Respir Crit Care Med 1999; 160: 216-220.

153 Montuschi P, Collins JV, Ciabattoni G, et al. Exhaled 8isoprostane as an in vivo biomarker of lung oxidative stress in patients with COPD and healthy smokers. Am J Respir Crit Care Med 2000; 162: 1175-1177.

154 Choi AMK, Alam J. Heme oxygenase-1: function, regulation, and implication of a novel stress-inducible protein in oxidant-induced lung injury. Am J Respir Crit Care Med 1996; 15: 9-19.

155 Tenhumen R, Marver HS, Schmid R. The enzymatic conversion of heme to bilirubin by microsomal heme oxygenase. Proc Natl Acad Sci USA 1968; 61: 748-755.

156 Abraham NG, Drummond GS, Lutton JD, Kappas A. The biological significance and physiological role of heme oxygenase. Cell Physiol Biochem 1996; 6: 129-168.

157 Willis D, Moore AR, Frederick R, Willoughby DA. Heme oxygenase: a novel target for the modulation of the inflammatory response. Nature Med 1996; 2: 87-90. 